\title{
Utilization of acid pre-treated coconut dregs as a substrate for production of detergent compatible lipase by Bacillus stratosphericus
}

\author{
Nur Bainun Mohd Zin ${ }^{1}$, Busyra Mohamad Yusof ${ }^{1}$, Siti Nurbaya Oslan², Helmi Wasoh ${ }^{1,3}$, Joo Shun Tan", \\ Arbakariya B. Ariff ${ }^{1,3}$ and Murni Halim ${ }^{1,3^{*}}$ (D)
}

\begin{abstract}
In recent years, many efforts have been directed to explore the methods to reduce the production costs of industrial lipase by improving the yield and the use of low-cost agricultural wastes. Coconut dregs, which is a lignocellulosic by-product from coconut oil and milk processing plants, is rich in cellulose (36\%) and crude fat (9\%). A newly isolated Bacillus stratosphericus has been demonstrated to perform cellulose hydrolysis on coconut dregs producing fermentable sugars. The highest extracellular lipase activity of $140 \mathrm{U} / \mathrm{mL}$ has been achieved in submerged fermentation with acid pre-treated coconut dregs. The lipase was found to be active over a wide range of temperatures and $\mathrm{pHs}$. The activity of lipase can be generally increased by the presence of detergent ingredients such as Tween-80, cetyltrimethylammonium bromide, hydrogen peroxide and phosphate per sulphate. The great compatibility of lipase in commercial detergents has also underlined its potential as an additive ingredient in biodetergent formulations.
\end{abstract}

Keywords: Lipase, Bacillus stratosphericus, Coconut waste, Biodetergent, Submerged fermentation

\section{Introduction}

Lipases (triacylglycerol acyl hydrolase, E.C.3.1.1.3) are among the important classes of hydrolytic enzyme that can catalyse both hydrolysis and synthesis of esters (Chauhan et al. 2013). They hydrolyse triacylglycerides to fatty acids, diacylglycerol, monoacyl glycerol and glycerol at interface between oil and water (aqueous). In contrast, under non-aqueous condition, lipases will be able to catalyse reverse reactions such as esterification and trans-esterification. To date, detergent enzymes accounts for more than $37 \%$ of the world's total enzyme production and detergent industry (Dahiya and Rathi 2014). The increasing demand for biodetergent is mostly influenced by better washing performance as compared to the synthetic detergents and the public awareness on the potential hazardous effects by chemical detergent ingredients

\footnotetext{
*Correspondence: murnihalim@upm.edu.my

${ }^{3}$ Bioprocessing and Biomanufacturing Research Centre, Faculty of Biotechnology and Biomolecular Sciences, Universiti Putra Malaysia, 43400 UPM Serdang, Selangor, Malaysia

Full list of author information is available at the end of the article
}

and environmental pollution. The success of incorporating lipase in detergent formulations will promote a green technology by either partially or totally reducing the use of non eco-friendly chemical compounds.

The detergent lipases are produced by various microorganisms such as those belonged to Staphylococcus, Bacillus, Burkholderia and Pseudomonas genera (Niyonzima and More 2015). The commercially important bacterial lipases are usually extracellular enzymes and their bulk production is much easier than that of intracellular enzymes (Palaker et al. 2000). In detergent formulation, lipases are often added as either crude or partially purified form. In general, they are used as additives in detergent formulation to catalyse the removal of fat and oil stains under alkali and high temperatures (Banik and Prakash 2004). Nonetheless, to be effectively formulated as biodetergent, lipases must be able to withstand detergent ingredients including surfactants, bleaches and oxidising agents (Niyonzima and More 2015). Furthermore, they should exhibit a relatively high activity and remained their stability in alkali and high temperature 
conditions. Hence, continual search for novel lipases with compatibility as commercial laundry detergents is crucial to find the best functioning lipases in the washing condition without being sheared and destroyed along the washing processes.

Currently, the major bottlenecks faced by industrial enzyme producers are low yield and high production cost. For instant, media used for the production of hydrolases such as lipase generally involve expensive complex carbon and nitrogen sources that are responsible for as much as $70 \%$ raw material costs in extracellular enzyme fermentation (Jamrath et al. 2012). The exploitation of lignocelluloses materials including agroindustrial waste may hence serve as effective and cheap alternative in producing enzymes at appreciable level for commercial use. Furthermore, the use of agricultural residues for industrial purposes is more environmental friendly than other disposal methods commonly adopted nowadays. Coconut (Cocos nucifera L.) has been grown in more than 85 countries worldwide with Indonesia, Philippines, India, Brazil and Sri Lanka being among the top producers (Siddiq 2012). Coconut dregs is basically a residue from coconut oil and milk processing plants. This lignocelluloses biomass is abundantly available at low or without cost and commonly used as fertiliser, animal feed or simply left to decay on the fields (Sulaiman et al. 2013). Nonetheless, the utilisation of this by-product has been recently extended to more refined applications including as a nutrient rich substrate for oyster mushroom cultivation (Vetayasuporn 2007) and biodiesel production (Sulaiman et al. 2013) owing to its high coconut oil content. The solid coconut waste from coconut milk extraction process was found to have up to $24 \mathrm{wt} \%$ oil content (Sarina et al. 2013). In addition, the coconut waste comprises high concentration of directly fermentable carbohydrates that can be converted into free sugar by a simple chemical pre-hydrolysis during sterilisation of the medium followed by enzymatic action of the bacteria during fermentation (Ding et al. 2012).

Therefore, this paper aimed to produce lipase compatible biodetergent by utilising coconut dregs to serve as a substrate supplying carbon source as well as triglyceride inducers for efficient and cheap lipase biodetergent production.

\section{Materials and methods}

\section{Isolation of lipase producers}

Samples of $1 \mathrm{~mL}$ were taken from palm oil mill effluent (POME) sludge, hot springs and used cooking oil, whereas $1 \mathrm{~g}$ of sample was taken from contaminated food and mixed with $9 \mathrm{~mL}$ sterile distilled water. The solutions were agitated at $150 \mathrm{rpm}$ under $37{ }^{\circ} \mathrm{C}$ in an incubator shaker for $30 \mathrm{~min}$ to enrich the microbes. The solutions were then diluted up to $10^{-6}$ and plated on Luria Bertani (LB) (Sigma Aldrich, United State) agar plates. The plates were incubated at $37^{\circ} \mathrm{C}$ in an oven for $18 \mathrm{~h}$ (overnight) to obtain single colonies. The single colonies were then picked and streaked on another LB agar plates and subsequently grown for another $18 \mathrm{~h}$. The steps were repeated until pure cultures of the colonies were obtained. The strains were then preserved in sterile $20 \%(\mathrm{v} / \mathrm{v})$ glycerol in $\mathrm{LB}$ broth at $-80^{\circ} \mathrm{C}$.

For screening of lipase producing bacteria, the bacteria pure cultures on the LB plates were streaked on selective plate media, which is Rhodamine B (28 g nutrient agar, $4 \mathrm{~g}$ sodium chloride, $10 \mathrm{mg}$ rhodamine $\mathrm{B}, 10 \mathrm{~mL}$ olive oil in $1 \mathrm{~L}$ distilled water with $\mathrm{pH} 7$ adjusted by the addition of sodium hydroxide prior autoclaved). The plates were incubated in an oven at $37{ }^{\circ} \mathrm{C}$ for about $1-2$ days. The bacterial colonies were then observed for a pink-orange fluorescence zone hydrolysis around bacterial colony under UV $350 \mathrm{~nm}$, thus indicating the positive lipase producing bacteria.

For cellulase activity test, $5 \mu \mathrm{L}$ of overnight grown culture was spot plated on carboxymethylcellulose (CMC) agar plate $\left(0.2 \% \mathrm{NaNO}_{3}, 0.1 \% \mathrm{~K}_{2} \mathrm{HPO}_{4}, 0.05 \% \mathrm{MgSO}_{4}\right.$, $0.05 \% \mathrm{KCl}, 0.2 \% \mathrm{CMC}$ sodium salt, $0.02 \%$ peptone and $1.7 \%$ agar). The plates were incubated at $37{ }^{\circ} \mathrm{C}$ for $48 \mathrm{~h}$. They were then flooded with Gram's iodine for 3-5 min and observed for a zone hydrolysis around bacterial colony.

\section{Identification of lipase producer}

Genomic DNA was extracted from the isolate using phenol-chloroform method as described by Sambrook and Russell (2001). The 16S rRNA gene was amplified with two universal eubacterial primers: $\mathrm{fD} 1$ and $\mathrm{rD} 1$. The PCR product was purified using an Agarose Gel DNA Purification Kit (Roche, Switzerland) and cloned into pTZ57R/T according to manufacturer's structure. DNA sequencing was carried out by dideoxy chain termination method (Macrogen, Seoul, Korea) using pUC/M13 primers.

The 16S rRNA gene sequence was analysed through NCBI BLAST (http://www.ncbi.nlm.nih.gov/blast/) and EzTaxon servers (http://www.eztaxon.org/). The most similar sequences were aligned in Molecular Evolutionary Genetics Analysis (MEGA) 5.01 software and a phylogenetic tree was made by the neighbour-joining $(\mathrm{NJ})$ method with 1000 bootstrap replicates in the MEGA (Tamura et al. 2011).

\section{Pre-treatment of coconut dregs}

A sample of coconut dregs collected from local market in Serdang, Selangor, Malaysia was ground and sieved into $1 \mathrm{~mm}$ particle size. It was separately mixed with different concentrations of sulphuric acid (0.2, 0.6 and $1 \%)$ 
and sodium hydroxide $(1,3$, and $5 \%)$ at $50{ }^{\circ} \mathrm{C}$ for 3 days. Pre-treatment using different concentrations of cellulase $(10,000$ and $30,000 \mathrm{U} / \mathrm{g}$ of cellulysin (Merck, Malaysia) was done at $40{ }^{\circ} \mathrm{C}$ and $\mathrm{pH} 4$ for 3 days. One unit of cellulose was measured for decomposing activity using a filter paper substrate at $40{ }^{\circ} \mathrm{C}$ and $\mathrm{pH} 4$. At the end of the hydrolysis, liquid fraction from hydrolysate was filtered to be analysed for glucose concentration by glucose assay kit (Merck, Malaysia). The residual part was dried at $80{ }^{\circ} \mathrm{C}$ until a constant weight is achieved. The dried coconut dregs was kept in a dry state and used throughout the experiments.

\section{Feedstock characterisation}

The characterisation of untreated coconut dregs was conducted according to the acid detergent fibre, neutral detergent fibre, and acid detergent lignin (ADF-NDFADL) method (Goering and van Soest 1970). Hemicellulose and cellulose were calculated based on Eqs. 1 and 2.

$$
\begin{aligned}
& \text { Hemicellulose (\%) }=\text { NDF (\%) - ADF (\%) } \\
& \begin{aligned}
\text { Cellulose (\%) }= & \text { NDF (\%) - Hemicellulose (\%) } \\
& - \text { Lignin (\%) }
\end{aligned}
\end{aligned}
$$

Meanwhile, the crude fat of untreated coconut dregs was conducted by adopting Soxhlet extraction method (Aji et al. 2015). The grounded coconut dregs were packed into the extraction chamber of the Soxhlet extractor while a solvent (n-hexane) was poured into the round bottom flask of the extractor. The whole set up was mounted on a heating mantle at $65{ }^{\circ} \mathrm{C}$ and allowed to reflux for about $8 \mathrm{~h}$. The extract was filtered and evaporated using a rotary evaporator to isolate the free flow lipid from the solvent. The extracted oil was further evaporated in an oven at $150{ }^{\circ} \mathrm{C}$ to eliminate any moisture and residue solvent that may be present. The weight of oil produced and residue were measured to ascertain the percentage of the oil content.

The crude protein of untreated coconut dregs was conducted according to Kjeldahl method (Zainuddin et al. 2014).

On the other hand, the crude fibre of untreated coconut dregs was carried out according to that proposed by Zainuddin et al. (2014).

\section{Lipase production in submerged fermentation}

$5 \%$ overnight culture of B. stratosphericus PW3 (Microbial Culture Collection Unit (UNiCC), UPM: UPMC 1196; GenBank accession number: KY797998) was inoculated in a liquid medium containing $50 \mathrm{~mL}$ basal media $\left(0.01 \% \quad \mathrm{MgSO}_{4} \cdot 7 \mathrm{H}_{2} \mathrm{O}, 0.1 \% \mathrm{KH}_{2} \mathrm{PO}_{4}\right.$ and $0.5 \%$ peptone) supplemented either with $1.5 \%$ of $0.2 \%$ acid pre-treated coconut dregs, $1.5 \%$ of $5 \%$ alkali pre-treated coconut dregs, $1.5 \%$ un-treated coconut dregs, $1.5 \%$ of $0.2 \%$ acid pre-treated coconut dregs with $3.5 \%$ coconut oil or without any supplementation (control experiment). The $250 \mathrm{~mL}$ flasks were incubated for $32 \mathrm{~h}$ at $\mathrm{pH} 7,37^{\circ} \mathrm{C}$ under shaking on a rotary shaker at $200 \mathrm{rpm}$. Sampling was done at time interval and cell free supernatant obtained by centrifugation at $10,000 \mathrm{rpm}, 10 \mathrm{~min}$ at $4{ }^{\circ} \mathrm{C}$, which was considered as the crude lipase.

\section{Lipase assay}

Lipase activity was estimated by spectrophotometric assay using $p$-nitrophenyl-laurate (pNPL) as a substrate with slightly modifications (Winkler and Stuckmann 1979). The reaction mixture comprised $0.001 \mathrm{~mL}$ crude lipase, $0.089 \mathrm{~mL} 0.05 \mathrm{M}$ phosphate buffer (pH 7) and $0.01 \mathrm{~mL}$ of $0.01 \mathrm{M}$ pNPL in DMSO. The mixture was incubated at $50{ }^{\circ} \mathrm{C}$ for $5 \mathrm{~min}$ and the reaction was stopped using $0.1 \mathrm{~mL}$ absolute ethanol. The absorbance was determined at $410 \mathrm{~nm}$. One unit of lipase activity was calculated as $\mu \mathrm{mol}$ of $p$-nitrophenol (pNP) released per minute per millilitre of enzyme solution under standard assay conditions.

\section{Partial characterisation of $B$. stratosphericus lipase Effects of temperature and $p H$ on lipase activity}

The optimum temperature for lipase activity of B. stratosphericus was determined by assaying the lipase activity at different temperatures ranging from 40 to $70{ }^{\circ} \mathrm{C}$ at $\mathrm{pH}$ 7 using pNPL as substrate. Relative lipase activity was measured in percentage of lipase activity of the sample with respect to the lipase activity of the control sample, which was kept at $4{ }^{\circ} \mathrm{C}$.

Optimum $\mathrm{pH}$ was determined by assaying the lipase activity at different $\mathrm{pH}$ ranging from 4 to 10 at $50{ }^{\circ} \mathrm{C}$ in buffer solutions using pNPL as substrate. The buffer solutions used are $0.05 \mathrm{M}$ sodium acetate $\mathrm{pH} 4$ and $5,0.05 \mathrm{M}$ sodium phosphate $\mathrm{pH} \mathrm{6,7}$ and $\mathrm{pH} 8,0.05 \mathrm{M}$ glycine $\mathrm{NaOH}$ pH 9 and 10.

\section{Effects of metal ions, inhibitor, surfactants and oxidising agents on lipase stability}

The effects of various metal ions, inhibitor, surfactants and oxidising agents toward lipase activity were investigated at 1:1 (v/v) ratio with crude lipase and pre-incubated for $1 \mathrm{~h}$ at $50{ }^{\circ} \mathrm{C}$. The metal ions used are $0.01 \mathrm{M}$ of calcium chloride, cobalt chloride, zinc chloride, sodium chloride, potassium chloride, iron (III) chloride, manganese chloride and magnesium chloride, which contributed as $\mathrm{Ca}^{2+}, \mathrm{Co}^{2+}, \mathrm{Zn}^{2+}, \mathrm{Na}^{2+}, \mathrm{K}^{+}, \mathrm{Fe}^{3+}$, $\mathrm{Mn}^{2+}$, and $\mathrm{Mg}^{2+}$, respectively. For inhibitor, $0.01 \mathrm{M}$ ethylenediaminetetraacetic acid (EDTA) was used. The surfactants utilised are Tween-20, Tween-40, Tween80, Triton X-100, sodium dodecyl sulphate (SDS) and 
cetyltrimethylammonium bromide (CTAB). Moreover, the oxidising agents used are hydrogen peroxide $\left(\mathrm{H}_{2} \mathrm{O}_{2}\right)$, sodium hypochlorite $(\mathrm{NaClO})$, and phosphate persulphate $\left(\mathrm{K}_{2} \mathrm{~S}_{2} \mathrm{O}_{8}\right)$. The surfactants and oxidising agents were tested at different concentrations of $0.5,1.0,1.5,2.0$, 3.0 and $5.0 \%$. The residual lipase activity was measured in percentage of lipase activity of the sample with respect to the lipase activity of the control sample. The control is the crude lipase incubated under similar conditions with the lipase activity taken as $100 \%$.

\section{Effects of commercial detergents on lipase stability}

The stability of lipase in the presence of locally available commercial detergents was determined using $7 \mathrm{mg} /$ $\mathrm{mL}(\mathrm{w} / \mathrm{v})$ washing powders such as biodetergent 1 , biodetergent 2, detergent 1 , detergent 2 and detergent 3 . Endogenous enzymes present in the biodetergent 1 and biodetergent 2 were first inactivated by incubating the detergent solutions at $90{ }^{\circ} \mathrm{C}$ for $1 \mathrm{~h}$ prior adding crude lipase from $B$. stratosphericus. The effects of commercial detergents were investigated at 1:1 (v/v) ratio with crude lipase and pre-incubated for $1 \mathrm{~h}$ at $50{ }^{\circ} \mathrm{C}$. The residual lipase activity was measured in percentage of lipase activity of the sample with respect to the lipase activity of the control sample. The control is the crude lipase incubated under similar conditions with the lipase activity taken as $100 \%$.

\section{Results}

\section{Screening and identification of lipase producing bacteria}

The positive lipase bacteria producers were confirmed by the production of orange-pink fluorescent colonies on Rhodamine B agar medium under UV light. Among the 22 isolates obtained from various sources including hot springs, POME sludge, spoiled foods and used cooking oil, only bacteria strains SA (isolated from hotsprings), PW3 (isolated from POME sludge) and PW2 (isolated from POME sludge) showed the highest zone formation. These three newly isolated lipase producers were further screened for bacterial cellulase activity on CMC containing plates. Based on the production of zone hydrolysis, only PW3 strain was found positive for cellulase production on CMC agar plate. The PW3 strain was then identified as Bacillus stratosphericus PW3 (GenBank accession number: KY797998) with $100 \%$ similarity to Bacillus stratosphericus 41KF2a based on 16S rRNA gene sequence analysis.

\section{Effects of acid pre-treatment of glucose production in coconut dregs}

The proximate analysis of coconut dregs is displayed in Table 1. Coconut dreg sample was found to show 9.35\% of crude fat content. From the analysis, lignocellulose of
Table 1 Proximate analysis of coconut dregs

\begin{tabular}{lc}
\hline Composition & Percentage, \% \\
\hline Crude protein & 6.54 \\
Crude fibre & 27.33 \\
Crude fat & 9.35 \\
Cellulose & 36.08 \\
Hemicellulose & 12.58 \\
Lignin & 9.81 \\
\hline
\end{tabular}

the coconut dregs was seen consisting $36.08 \%$ cellulose, $12.58 \%$ hemicellulose and $9.81 \%$ lignin.

Pre-treatment of the coconut dregs was conducted using different concentrations of sulphuric acid and sodium hydroxide to liberate glucose from tightly associated chain as cellulose is crystalline. Different concentrations of sulphuric acid in the range of $0.2-1 \%$ demonstrated no effect on glucose production in coconut dregs hydrolysate but treatment times substantially influenced (Fig. 1). $48 \mathrm{~h}$ of incubation at $50{ }^{\circ} \mathrm{C}$ was required to obtain the optimum glucose at $0.2 \mathrm{~g} / \mathrm{L}$ for the tested acid concentrations. Prolonging the incubation period to $72 \mathrm{~h}$ has resulted in drastic reduction of glucose concentration. Unlike acid pre-treatment, alkali concentration and pre-treatment time both contributed to the glucose production. The highest glucose concentration of $0.65 \mathrm{~g} / \mathrm{L}$ was achieved when coconut dregs was incubated with $5 \%$ of sodium hydroxide in $27 \mathrm{~h}$. Nonetheless, glucose was dramatically decreased to $0.14 \mathrm{~g} / \mathrm{L}$ at $72 \mathrm{~h}$. A control experiment was performed to confirm the role of cellulase enzyme in hydrolysing cellulose to glucose from coconut dregs. The presence of commercial cellulase enzyme showed a drastic increment in glucose production from coconut dregs as $1.4 \mathrm{~g} / \mathrm{L}$ glucose was achieved when 30,000 U/g cellulose present during $72 \mathrm{~h}$ of incubation. The ability of lipase producer $B$. stratosphericus to self-produce cellulase displayed its potential to be exploited for lipase production using lignocellulosic waste such as coconut dregs as a cheap substrate.

\section{Production of lipase in submerged fermentation}

Extracellular lipase production by $B$. stratosphericus using coconut dregs was performed under submerged fermentation (Fig. 2). Basal media consists of $0.01 \%$ $\mathrm{MgSO}_{4} \cdot 7 \mathrm{H}_{2} \mathrm{O}, 0.1 \% \mathrm{KH}_{2} \mathrm{PO}_{4}$ and $0.5 \%$ peptone was supplied with $1.5 \%$ of acid, alkali or untreated coconut dregs as a sole carbon source. Although glucose was found higher in hydrolysate of alkali treated as compared to acid treated, the maximum lipase activity achieved in fermentation with acid treated coconut dregs was twofold higher $(140 \mathrm{U} / \mathrm{mL})$. A low enzyme activity of $32 \mathrm{U} / \mathrm{mL}$ was quantified when the basal media in the presence of 


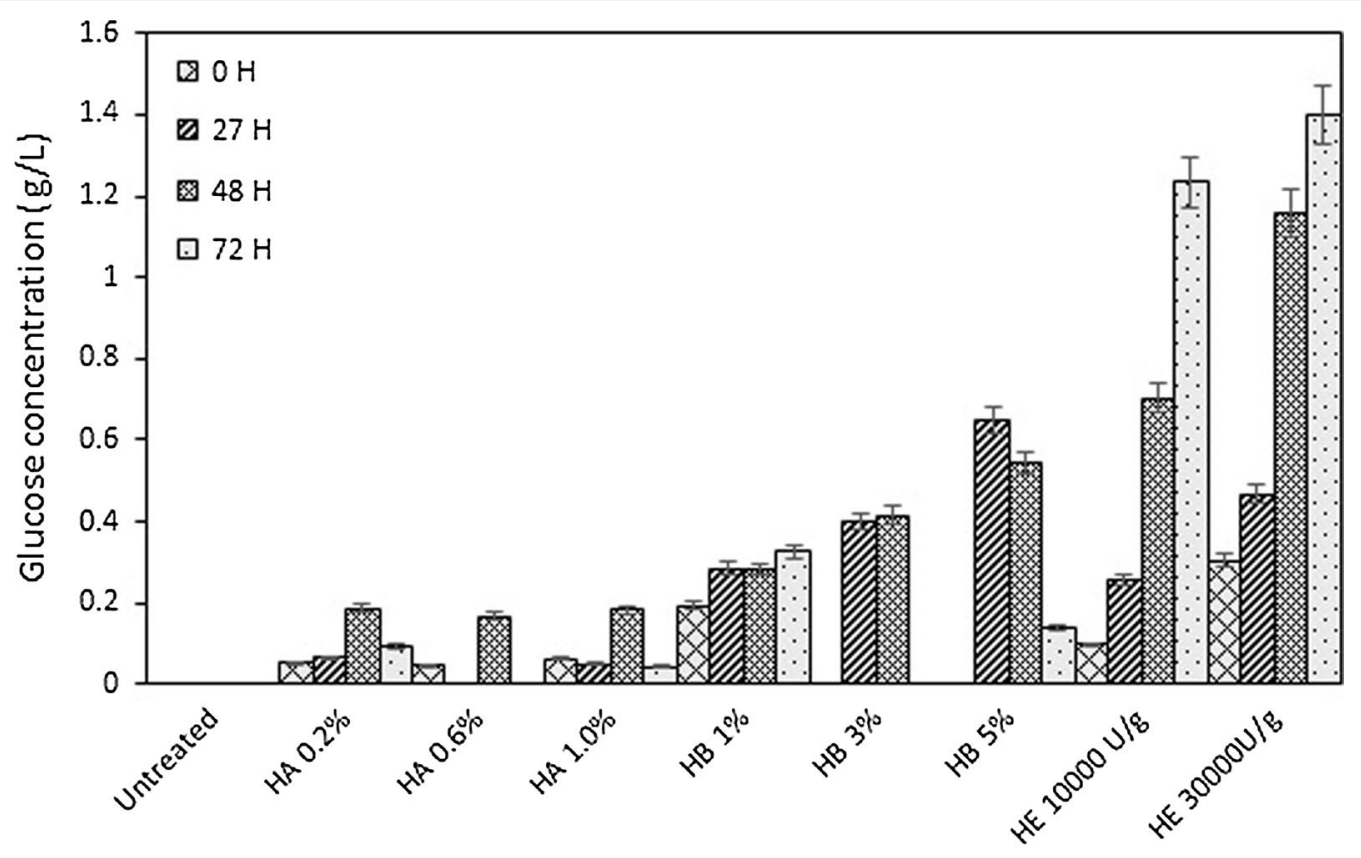

Pre-treatment

Fig. 1 Pretreament of coconut dregs. Glucose residual was determined for coconut dregs samples that were pre-treated with different concentrations of HA: sulphuric acid, HB: sodium hydroxide and HE: cellulase for 3 days at $50^{\circ} \mathrm{C}$

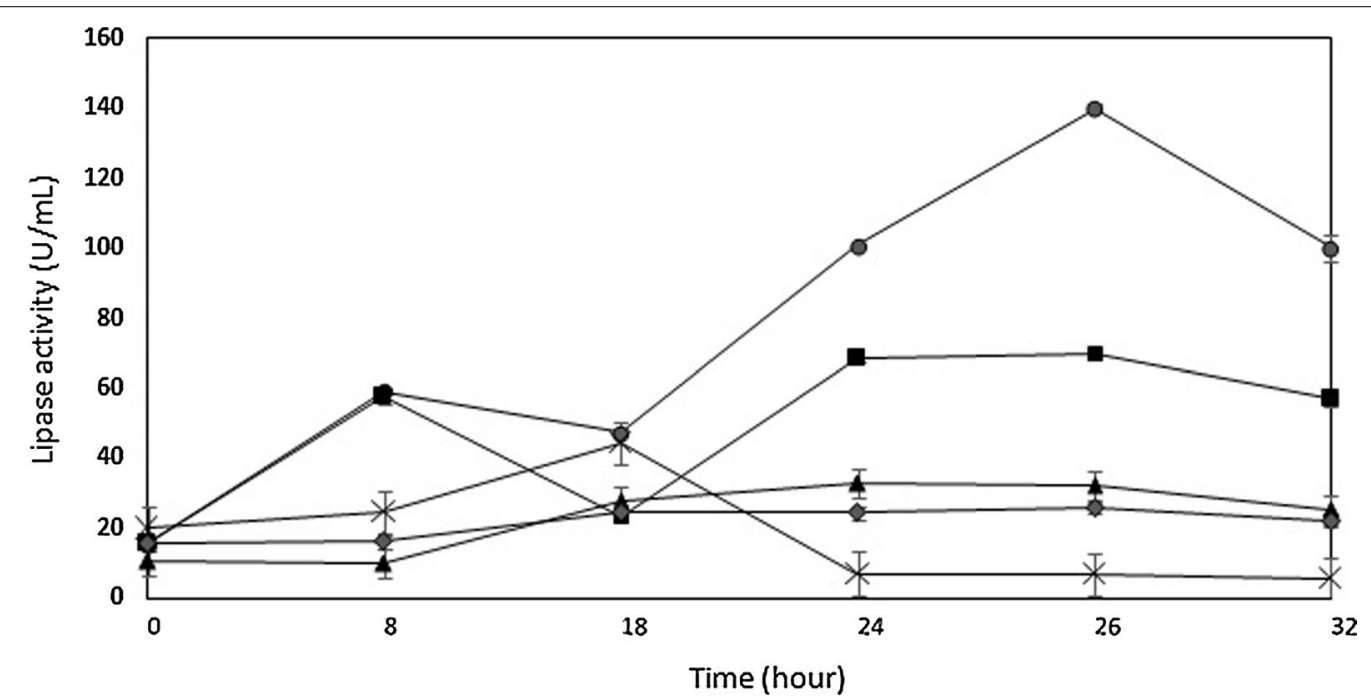

Fig. 2 Production of B. stratosphericus lipase in submerged fermentation. Lipase activity was determined for submerged fermentations using (a) basal media (diamond); (b) basal media with acid pre-treatment coconut dregs (circle); (c) basal media with alkali pre-treatment coconut dregs (square); (d) basal media with acid pre-treatment coconut dregs and coconut oil (triangle); and (e) basal media with un-treated coconut dregs ( $\mathrm{X}$ ) carbon. The fermentations were performed at $37^{\circ} \mathrm{C}$ and $\mathrm{pH}$ 7. Error bars represent one standard deviation about the mean $(n=3)$

acid treated coconut dregs was supplemented with $3.5 \%$ coconut oil. Meanwhile only a maximum of $44 \mu / \mathrm{mL}$ lipase was obtained with untreated coconut dregs. The lipase activity was further reduced to only $26 \mathrm{U} / \mathrm{mL}$ when $B$. stratosphericus was grown in the basal media without coconut dregs. 


\section{Partial characterisation of $B$. stratosphericus lipase} Effects of temperature and $\mathrm{pH}$ on lipase activity

As depicted in Fig. 3, the lipase activity has increased with increasing temperature and retained 100 and 93\% of its activities at 50 and $60{ }^{\circ} \mathrm{C}$, respectively. Thereafter, the lipase activity dropped to approximately $62 \%$ when incubated at 70 and $80{ }^{\circ} \mathrm{C}$. Hence, B. stratosphericus lipase has preferred the high temperature of $50{ }^{\circ} \mathrm{C}$ for maximal activity although the lipase was active over a broad range of temperature between 30 and $80^{\circ} \mathrm{C}$. The
B. stratosphericus lipase exhibited its optimum lipolytic activity (100\%) at $\mathrm{pH} 7$ and the activity was retained by $60-70 \%$ at $\mathrm{pH} 4-10$.

\section{Effects of detergent ingredients on lipase stability}

The behaviour of B. stratosphericus lipase in the presence of a few metal ions is shown in Fig. 4a. The lipase activity was inhibited by all the metal ions $\left(\mathrm{Ca}^{2+}, \mathrm{Co}^{2+}, \mathrm{Zn}^{2+}\right.$, $\mathrm{Na}^{2+}, \mathrm{K}^{+}, \mathrm{Fe}^{3+}, \mathrm{Mn}^{2+}$, and $\mathrm{Mg}^{2+}$ ) tested at concentration of $0.01 \mathrm{M}$. Among these, $\mathrm{Ca}^{2+}$ and $\mathrm{Mg}^{2+}$ have mostly
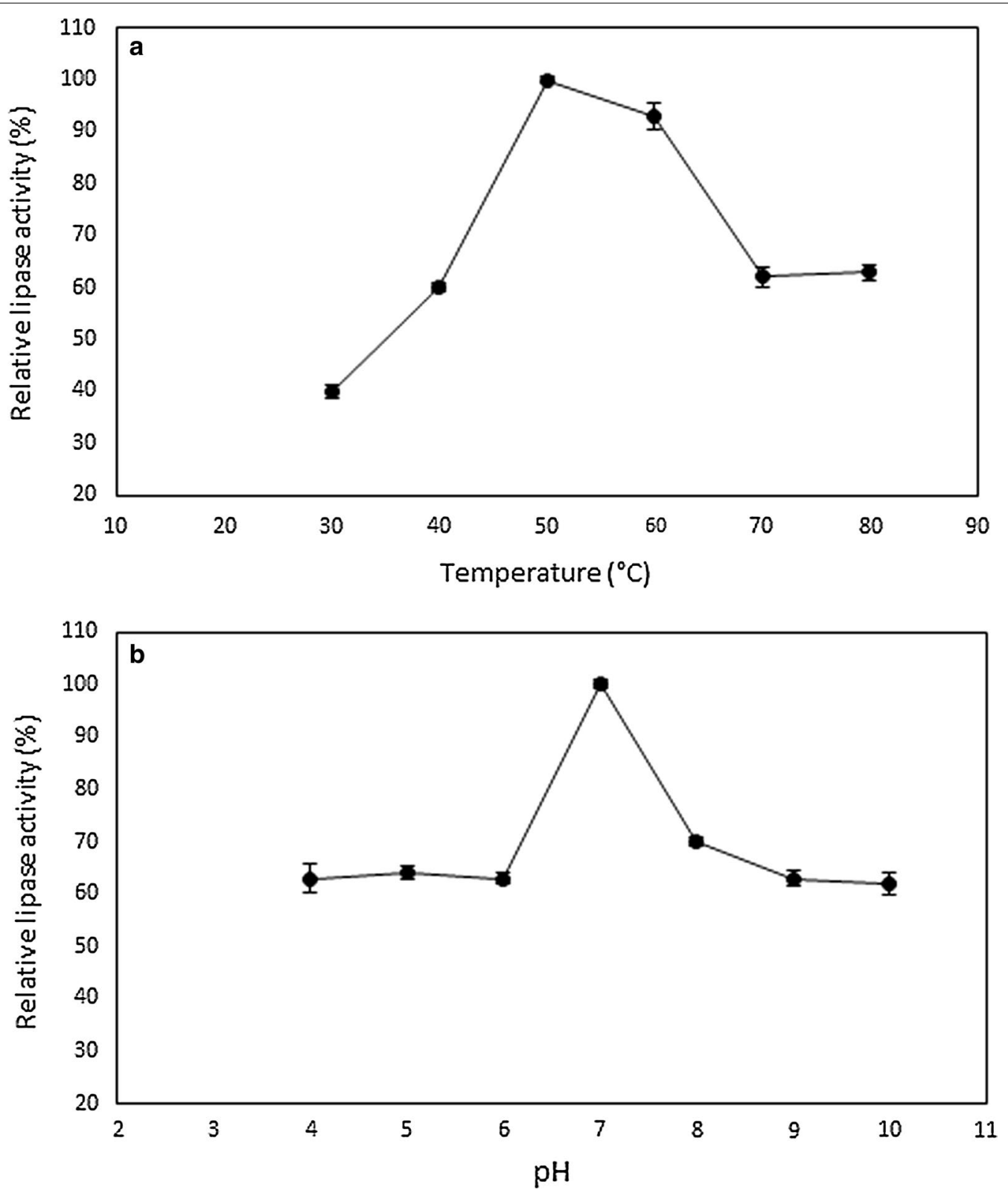

Fig. 3 Effect of different temperature and pH on lipase activity. Relative activity of $B$. stratosphericus lipase incubated at different a temperature and b $\mathrm{pH}$ was determined. Error bars represent one standard deviation about the mean $(n=3)$ 

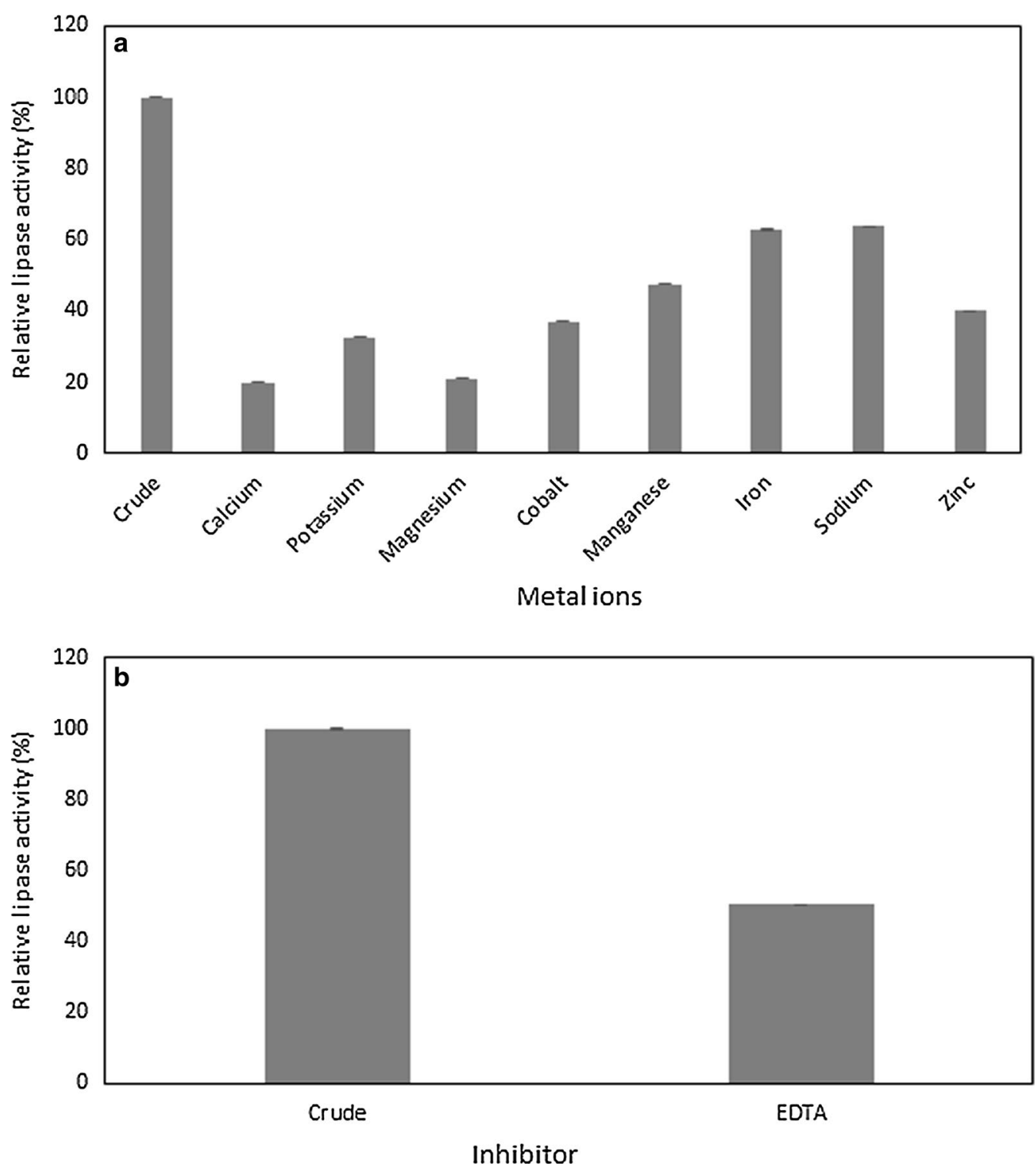

Fig. 4 Effect of metal ions and inhibitor on lipase activity. Residual activity of B. stratosphericus lipase incubated with $0.01 \mathrm{M}$ of a metal ions (Ca ${ }^{2+}$, $\mathrm{Co}^{2+}, \mathrm{Zn}^{2+}, \mathrm{Na}^{2+}, \mathrm{K}^{+}, \mathrm{Fe}^{3+}, \mathrm{Mn}^{2+}$, and $\mathrm{Mg}^{2+}$ ); and $\mathbf{b}$ inhibitor [ethylenediaminetetraacetic acid (EDTA)] for $1 \mathrm{~h}$ at $50^{\circ} \mathrm{C}$ was determined. Error bar represents one standard deviation about the mean $(n=3)$

inhibited lipase as can be seen by the residual activity of only $20 \%$ after $1 \mathrm{~h}$ incubation at $50^{\circ} \mathrm{C}$.

Based on the result in Fig. 4b, lipase was moderately inhibited by $1 \mathrm{mM}$ EDTA and retained $50.49 \%$ of its residual activity after $1 \mathrm{~h}$ incubation at $50^{\circ} \mathrm{C}$.

The effects of non-ionic surfactants at concentrations in the range of $0.5-5 \%(\mathrm{v} / \mathrm{v})$ on lipase activity was studied as depicted in Fig. 5a. The result showed that the lipase activity of B. stratosphericus has slightly increased by $3.69 \%$ from $100 \%$ crude residual activity of the control at $0.5 \%(\mathrm{v} / \mathrm{v})$ of Tween-80. On the other hand, the activity of $B$. stratosphericus lipase was only partially retained when incubated in $0.5 \%(\mathrm{v} / \mathrm{v})$ of Tween-20, Tween-40 and Triton X-100. In general, all tested non-ionic surfactants showed a similar pattern of decreasing residual activity with increasing concentrations. Among these, the lipase activity was strongly inhibited by $5 \%(\mathrm{v} / \mathrm{v})$ of Tween- 20 . Figure $5 \mathrm{~b}$ shows the effects of anionic surfactant, SDS at concentrations of $0.5-5 \%(\mathrm{v} / \mathrm{v})$ on B. stratosphericus lipase. The highest lipase activity was retained at 55\% when incubated in 1.5 and $2 \%(\mathrm{v} / \mathrm{v})$ of SDS. Meanwhile, lipase activity was enhanced by $47.54 \%$ above $100 \%$ crude 

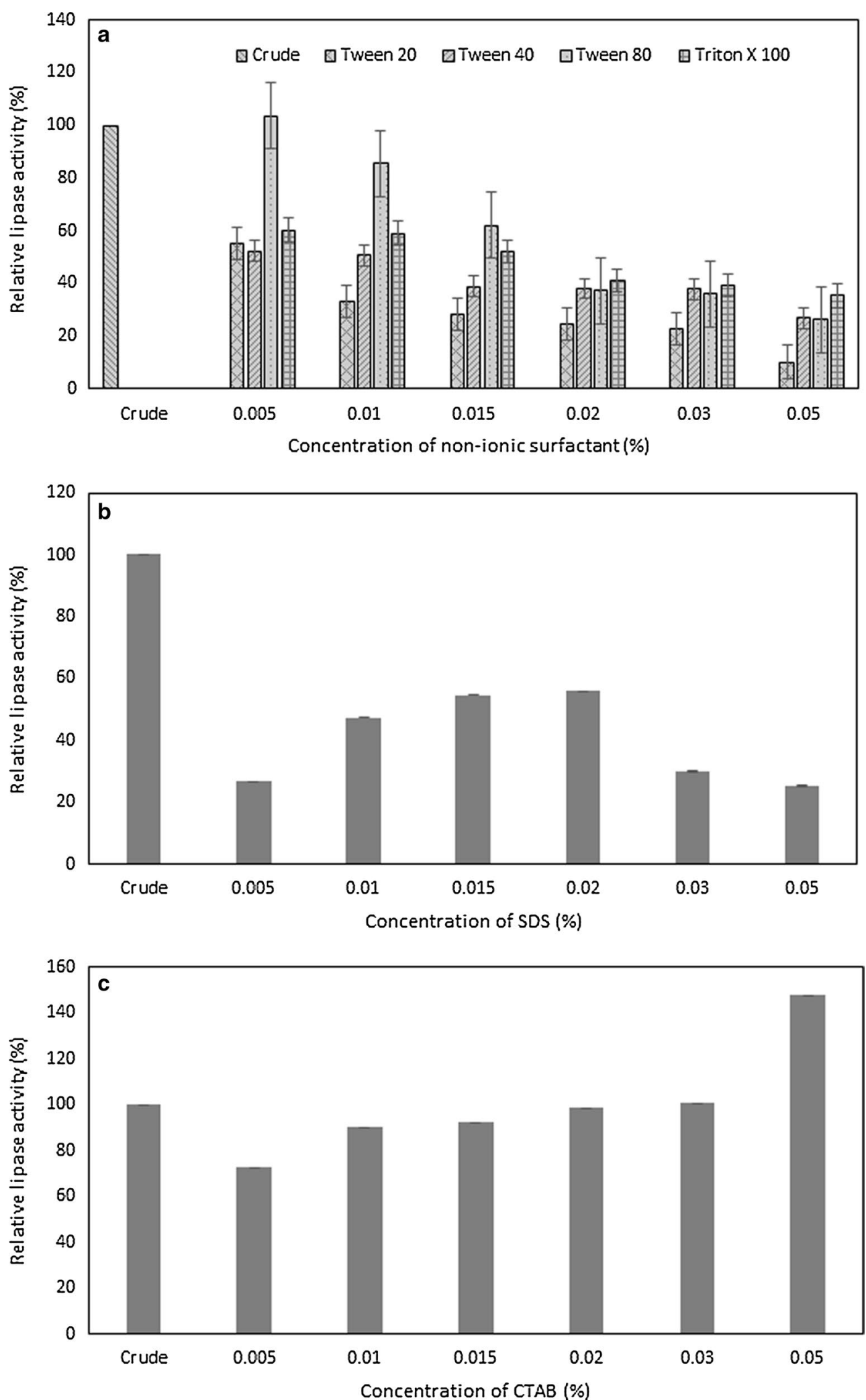

Fig. 5 Effect of surfactants on lipase activity. Residual activity of $B$. stratosphericus lipase incubated with various concentrations of a non-ionic surfactants (Tween-20, Tween-40, Tween-80 and Triton X-100); b anionic surfactant (SDS); and c cationic surfactant (CTAB) for $1 \mathrm{~h}$ at $50^{\circ} \mathrm{C}$ was determined. Error bar represents one standard deviation about the mean $(n=3)$ 
residual activity when incubated with $5 \%(\mathrm{v} / \mathrm{v})$ of cationic surfactant, CTAB (Fig. 5c).

The effects of oxidising agents $\left(\mathrm{H}_{2} \mathrm{O}_{2}, \mathrm{NaClO}\right.$ and $\mathrm{K}_{2} \mathrm{~S}_{2} \mathrm{O}_{8}$ ) were tested on the lipase activity of $B$. stratosphericus as depicted in Fig. 6. It was apparent that the lipase activities were enhanced by the presence of 3 and $5 \%(\mathrm{v} / \mathrm{v}$ ) of hydrogen peroxide to 13.05 and $80.30 \%$ above $100 \%$ crude residual activity, respectively. Lipase was also found stable at 1.5, 2.0 and $3.0 \%(\mathrm{v} / \mathrm{v})$ potassium persulphate with $96.31,96.80$ and $100.74 \%$ relative residual activity, respectively.

\section{Effects of commercial detergents on lipase activity}

Compatibility of crude lipase from $B$. stratosphericus was determined on several commercial detergents. With so many laundry detergents available in local market, only five different brands were selected to be tested. Two of them are biodetergents (biodetergent 1 and biodetergent 2) formulated with unknown enzyme, while the other three are non-biological detergents (detergent 1, detergent 2 , detergent 3 ). Prior the compatibility test, the biodetergents were firstly dissolved into distilled water and heated in a water bath at $90{ }^{\circ} \mathrm{C}$ for $1 \mathrm{~h}$ to ensure that the availability of endogenous enzymes in the detergents was de-activated. The initial pHs of the diluted detergents were verified and determined to be alkaline. The lipase from B. stratosphericus was most stable in detergent 1 , detergent 2 and biodetergent 2 with approximately 100 , 85 and $90 \%$ residual activities, respectively, which were retained after $1 \mathrm{~h}$ incubation (Fig. 7). The lowest residual activity was recorded in biodetergent 1 with only $50 \%$ residual activity.

\section{Discussion}

Newly isolated $B$. stratosphericus from POME sludge was cultivated in acid pre-treated coconut dregs and characterised for biodetergent compatibility. Although B. stratosphericus is believed to primarily live in the stratosphere (Shivaji et al. 2006), atmospheric cycling is thought to bring the stratospheric bacteria to earth, explaining its presence in environments such as POME sludge, deep sea (Odisi et al. 2012) and seawater (Hentati et al. 2016). To date, reports on lipase production by $B$. stratosphericus were seemed very scarce. Among the very few, B. stratosphericus-LAMA 585 isolated from South Atlantic deep-sea environment was reported to be a good prospect for producing both lipase and cellulase enzymes (Odisi et al. 2012). Furthermore, the strain was capable of growing well in both rich and minimal medium and producing its mesophilic lipases and cellulases without inducers.

The successful utilisation of lignocellulosic waste including coconut dregs as a carbon source for bacterial growth requires a strain candidate that is also capable to perform cellulose hydrolysis producing fermentable sugars (Maki et al. 2009). To facilitate the enzyme access to the polysaccharides especially cellulose, acid and alkali pre-treatments of the lignocellulosic materials of coconut dregs have been proposed with the intentions to disorganise the plant cell wall structure and to remove lignin.

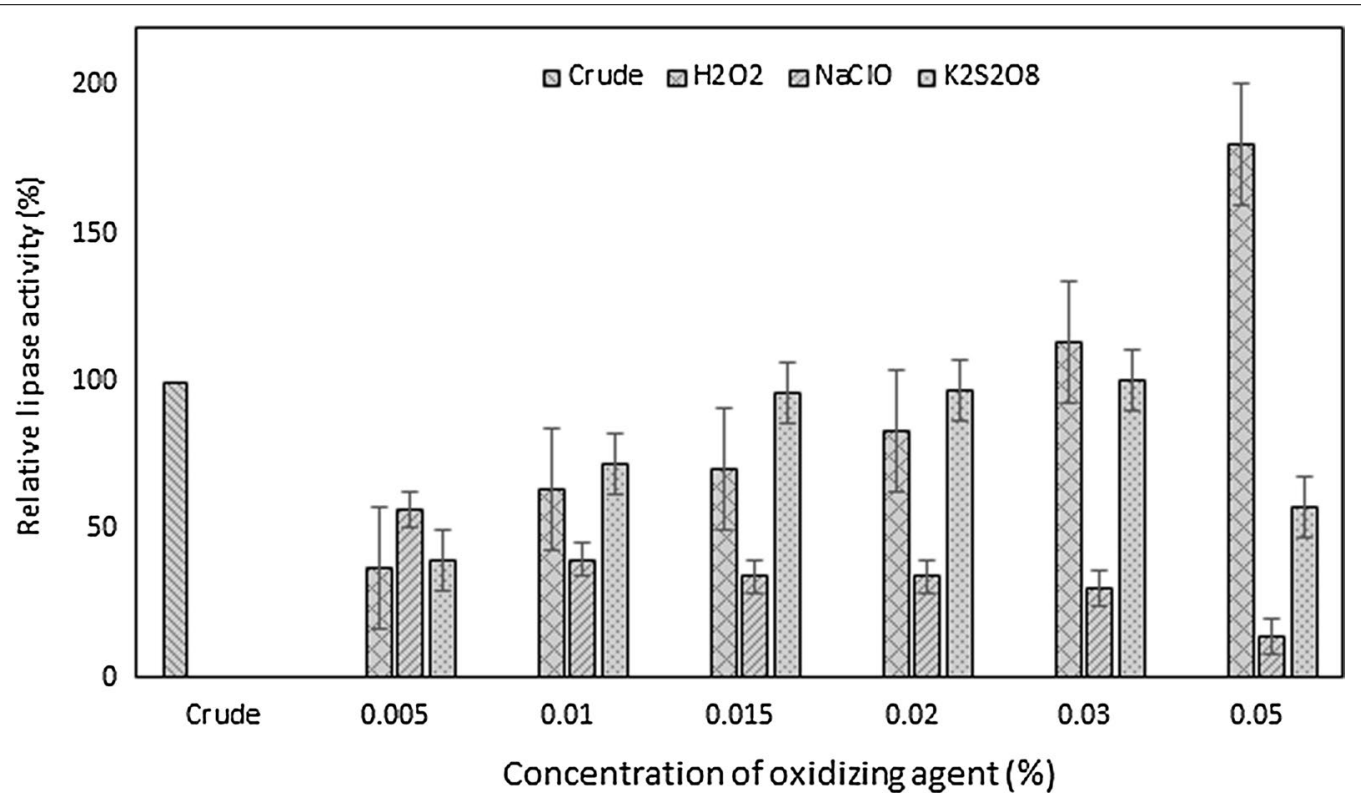

Fig. 6 Effect of oxidizing agents on lipase activity. Residual activity of $\mathrm{B}$. stratosphericus lipase incubated with various concentrations of $\mathrm{H}_{2} \mathrm{O}_{2}, \mathrm{NaClO}$ and $\mathrm{K}_{2} \mathrm{~S}_{2} \mathrm{O}_{8}$ for $1 \mathrm{~h}$ at $50^{\circ} \mathrm{C}$ was determined. Error bar represents one standard deviation about the mean $(n=3)$ 


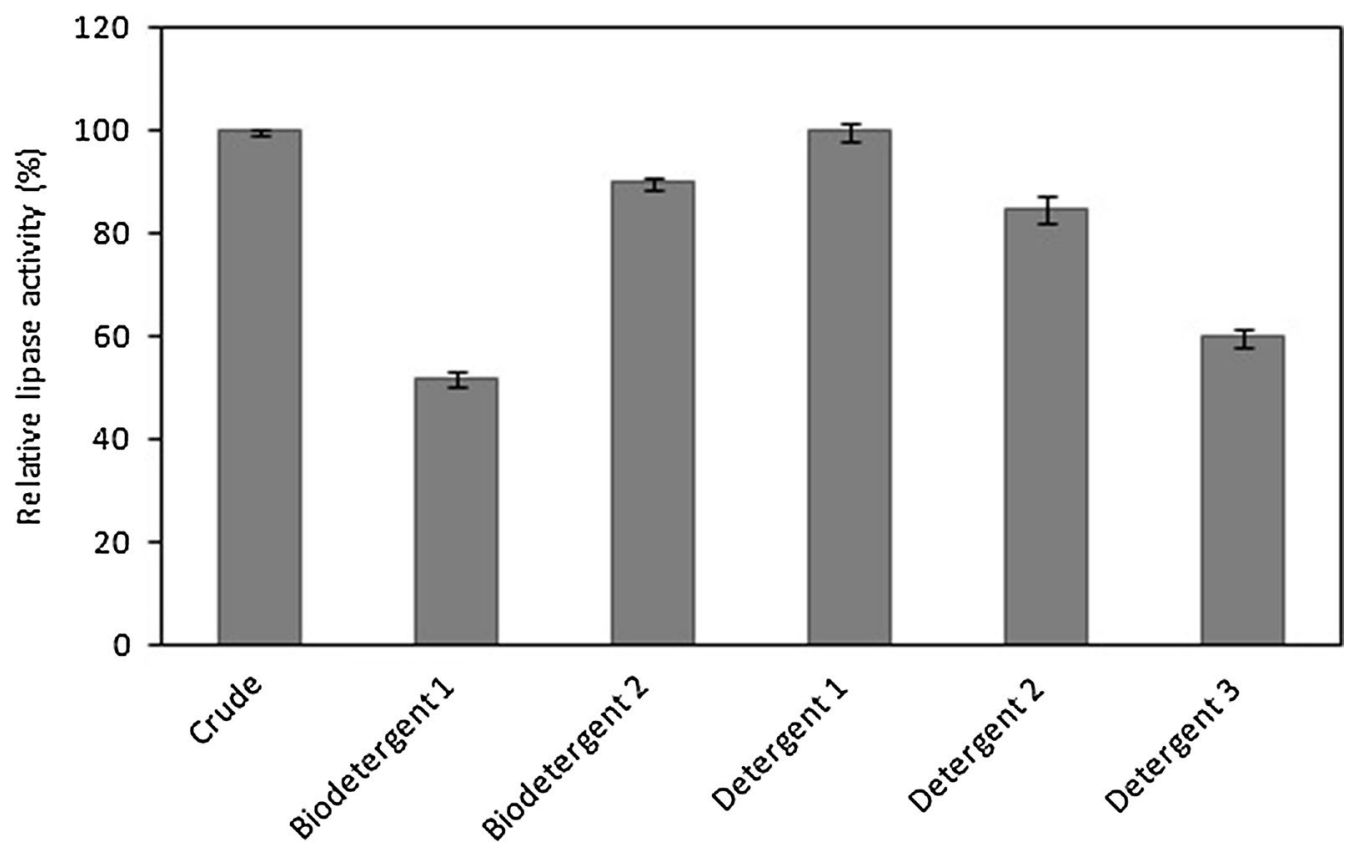

Commercial detergents

Fig. 7 Compatibility of lipase in commercial detergents. Residual activity of B. stratosphericus lipase incubated with commercial detergents for $1 \mathrm{~h}$ at $50{ }^{\circ} \mathrm{C}, \mathrm{pH} 7$ was determined. Error bar represents one standard deviation about the mean $(n=3)$

Pre-treatment of lignocelluloses is an essential step to make fermentable sugar available for the microbial biomass (Ashfaque et al. 2014). Nevertheless, incubation time seemed to have an enormous influence on both acid and alkali pre-treatments of coconut dreg. Glucose is the second intermediate product of cellulose biomass and further degradation will lead to the decomposition of 5-hydroxymethyl-furfural (Goto et al. 2004). Hence, an appropriate hydrolysis time is crucial to avoid the degradation of glucose. Bujang et al. (2013) reported $0.38 \mathrm{~g} / \mathrm{L}$ glucose was hydrolysed from coconut dregs sample only after 30 min incubation with $1 \%$ sulfuric acid at $130{ }^{\circ} \mathrm{C}$ whilst $48 \mathrm{~h}$ was required to obtained $0.2 \mathrm{~g} / \mathrm{L}$ glucose at $50{ }^{\circ} \mathrm{C}$ in this study. These results showed that besides incubation time, incubation temperature also plays a role in the acid hydrolysis rate of coconut dregs.

Carbon source with lipidic content such as coconut dregs may be exploited as an excellent substrate to trigger the associated genes responsible for lipase expression (Thakur et al. 2014). The highest lipase activity (140 U/ $\mathrm{mL}$ ) as observed in the cultivation with acid pre-treated coconuts dregs without the supplementation of coconut oil showed that $B$. stratosphericus prefers the readily available oil in the coconut dregs rather than the supplementary oil as an inducer for lipase production. Furthermore, the ability of $B$. stratosphericus to secrete lipase without supplementary lipid inducer presented the constitutive nature of this strain. In fact, many bacterial lipases were also reported to be constitutive in nature. For instance, lipase produced by Pseudomonas sp. BWS-5 was found to be constitutive in nature when there is no increment in lipase production at different olive oil concentrations (Sooch and Kauldhar 2013). Similarly, Thermomyces lanuginosus strains have also produced lipase in constitutive nature when different concentrations of olive oil in the medium gave no effect to the lipase production (Sreelatha et al. 2016). The presence of coconut oil (i.e., $3.5 \%)$ seemed to have an inhibitory effect on lipase activity. At certain concentrations, the oil layer in the media can interfere with oxygen transfer and may impede cell survival and growth (Kanmani et al. 2015). As expected, untreated coconut dregs did not favour lipase production when only a maximum of $44 \mathrm{U} / \mathrm{mL}$ lipase was obtained. Without pre-treatment, lignin in the lignocellulosic material cannot be eliminated. Lignin may block the degradation of cellulose into fermentable sugar by acting as an enzymatic barrier or an inhibitor for cellulase thus inhibit cellulose hydrolysing reaction (Kam et al. 2016). In general, the high yield of lipase obtained in the submerged fermentation using coconut dregs presented in this study has created another value-added for coconut waste. 
Preferred detergent lipase should have a sufficient lipase activity in washing solutions and adaptability in broad $\mathrm{pH}$ and temperature conditions (Wang et al. 2012). Generally, the $\mathrm{pH}$ of washing water is in the alkaline region (Niyonzima and More 2015). The 93-100\% relative activity at $50-60{ }^{\circ} \mathrm{C}$ and $60-70 \%$ relative activity at $\mathrm{pH}$ 4-10 indicated the thermostability and broad $\mathrm{pH}$ ranges of $B$. stratosphericus lipase. These features have justified its further investigation for biodetergent application.

Metal ions are known to have a significant function in influencing the structure and functions of an enzyme. Metal ions may be required to maintain the stability and activity of lipase enzyme. In this study, B. stratosphericus lipase did not depend on the metal ions to stabilise its reaction. This result is contradict with other studies where the lipase activity of Staphylococcus sp. ESW had increased by $20 \%$ in $2 \mathrm{mM}$ of calcium ion (Cheriff et al. 2011) and calcium ion has also enhanced the lipase activity of Staphylococcus pasteuri SNA59 (Aruna and Khan 2014). Hence, a further study is necessary to screen the effects of metal ion concentrations on lipase as it was reported that metal ions at certain concentration will be inhibiting instead of activating the enzyme (Lailaja and Chandrasekaran 2013).

In addition, the effects of inhibitor were studied to understand the involvement of amino acid on the activity of B. stratosphericus lipase. Stability in EDTA is essential for a lipase detergent since chelating agent aids in removing ions accounted for water hardness leading to a proper stain removal (Niyonzima and More 2015). However, EDTA is known as a potent inhibitor for metalloenzyme as it can sequester the presence of metal ions (Lailaja and Chandrasekaran 2013). This effect however can generally be overcome by supplementing excess suitable metal ions. B. stratosphericus lipase was found to be moderately inhibited by $0.01 \mathrm{M}$ EDTA after $1 \mathrm{~h}$ incubation. Nonetheless, metal ions tested in this study were also found to act as inhibitors for B. stratosphericus lipase and hence the EDTA inhibitory effects cannot be overcome by treatment with divalent ions at the tested concentrations. Previously, B. smithii lipase was also reported to be moderately affected by EDTA at various concentrations (Lailaja and Chandrasekaran 2013).

Besides $\mathrm{pH}$ and temperature, a good detergent lipase must be stable in the presence of various detergent ingredients (Niyonzima and More 2015). Surfactants are among the compounds in detergent formulation comprising molecules capable of changing the interfacial characteristics in solutions (Nerurkar et al. 2013). Among the tested non-ionic surfactants (Tween 20, Tween 40, Tween 80, and Triton X-100), only Tween 80 at $0.5 \%$ $(\mathrm{v} / \mathrm{v})$ has facilitated the enhancement of lipase activity
(103.69 U/mL) to above the control residual activity. Similarly, Tween-80 was reported to be a good anolog of lipidic substances and reliable substrate for detergent lipase from Bacillus sonorensis 4R (Hemlata et al. 2016). In the meantime, $B$. stratosphericus lipase was strongly inhibited by Tween 20. Some surfactants may cause alterations in the interfacial properties or changes of the lipase active site conformation preventing the binding of lipase to substrate, resulting in enzyme inactivation (Khoramnia et al. 2011). The partial inhibition of the activity of $B$. stratosphericus lipase in SDS might be due to the formation of lipase-anionic surfactant complexes that changes lipase active site conformation and lead to improper enzyme folding as well as causing enzyme inactivation (Prazeres et al. 2006) or obstructing the site for substrate adhesion (Khoo and Ibrahim 2009). Previously, several detergent compatible lipases were also reported to be inhibited by SDS. For instant, lipase from Pseudomonas aeruginosa KM110 had loss 30\% of its activity (Mobarak-Qamsari et al. 2011) while lipase from Acinetobacter calcoaceticus loss $76.3 \%$ activity compared to control when incubated in 1\% SDS (Wang et al. 2012). In contrast, CTAB has strongly helped to boost the activity of B. stratosphericus lipase. This increment can be attributed to the ability of CTAB as a cationic surfactant to solubilise the lipolysis products to prevent their interfacial accumulation (Jurado et al. 2007).

Oxidising or bleaching agents are frequently added in the detergent formulation for digestion and decolourisation of stains and organic materials during washing. Good stability of enzyme in bleach is relatively uncommon and can only be achieved by site-directed mutagenesis or protein engineering (Dutta and Ray 2009). Surprisingly, the present lipase was inherently stable towards some oxidising agents particularly hydrogen peroxide at high concentrations $[3-5 \%(\mathrm{v} / \mathrm{v})]$. Bisht et al. (2013) also reported that the activity of alkaline lipase from Pseudomonas aeruginosa mutant was enhanced in the presence of hydrogen peroxide with residual activity of $104.5 \%$. Meanwhile, a few other lipases only managed to either retained their residual activity equivalent to control (100\%) (Costa-Silva et al. 2014; Chauhan et al. 2013; Dutta and Ray 2009) or moderately (Chauhan et al. 2013; Wang et al. 2012; Weerasooriya and Kumarasinghe 2012) to strongly (Khoo and Ibrahim 2009) inhibited by hydrogen peroxide. The stability profile of $B$. stratosphericus lipase in oxidising agents proved its potential in detergent formulation.

The good compatibility of $B$. stratosphericus lipase with both biological and non-biological detergents may be mostly attributed to its better stability performance in alkaline $\mathrm{pH}$. The ability of the enzyme to retain above $80 \%$ activity in some selected detergents showed that 
although they are not strictly belonging to the alkaline lipase group, the enzyme can effectively serve as an additive in biodetergents with the right formulation. Furthermore, the thermostability feature of $B$. stratosphericus lipase is an added value as high temperatures are often preferable to remove difficult stain in cotton and synthetic materials (Bora and Bora 2012). Thus, it can be stated that the lipase from $B$. stratosphericus is suitable to be used as an additive in detergent formulation.

\begin{abstract}
Abbreviations
ADF: acid detergent fiber; NDF: neutral detergent fiber; ADL: acid detergent lignin; POME: palm oil mill effluent; LB: Luria-Bertani; CMC: carboxymethyl cellulose; pNPL: $p$-nitrophenyl-laurate; pNP: $p$-nitrophenol; SDS: sodium dodecyl sulphate; EDTA: ethylenediaminetetra acetic acid; CTAB: cetyltrimethylammonium bromide.
\end{abstract}

\section{Authors' contributions}

$\mathrm{MH}$ designed the study, analysed and interpreted the data, and wrote the manuscript. NBMZ conducted the study, collected the data, analysed and interpreted the data, and wrote the manuscript. BMY conducted the study and collected the data. SNO, HW, JST and ABA designed the study, analysed and interpreted the data. All authors read and approved the final manuscript.

\begin{abstract}
Author details
${ }^{1}$ Department of Bioprocess Technology, Faculty of Biotechnology and Biomolecular Sciences, Universiti Putra Malaysia, 43400 UPM Serdang, Selangor, Malaysia. ${ }^{2}$ Department of Biochemistry, Faculty of Biotechnology and Biomolecular Sciences, Universiti Putra Malaysia, 43400 UPM Serdang, Selangor, Malaysia. ${ }^{3}$ Bioprocessing and Biomanufacturing Research Centre, Faculty of Biotechnology and Biomolecular Sciences, Universiti Putra Malaysia, 43400 UPM Serdang, Selangor, Malaysia. ${ }^{4}$ Bioprocess Technology Division, School of Industrial Technology, Universiti Sains Malaysia, 11800 Gelugor, Penang, Malaysia.
\end{abstract}

\section{Acknowledgements}

We thank Universiti Putra Malaysia for the research facilities and funding (Grant No. GP-IPM/2014/9437700) throughout this research work.

\section{Competing interests}

The authors declare that they have no competing interests.

\section{Availability of data and materials}

All the data are presented in the main paper.

\section{Funding}

This study was funded by Universiti Putra Malaysia (Grant No. GPIPM/2014/9437700). The funding body has no role in the design of the study and collection, analysis, and interpretation of data and in writing the manuscript.

\section{Publisher's Note}

Springer Nature remains neutral with regard to jurisdictional claims in published maps and institutional affiliations.

Received: 30 March 2017 Accepted: 16 June 2017

Published online: 23 June 2017

\section{References}

Aji MM, Gutti B, Highina BK, Kyari SA (2015) Soxhlet extraction and characterisation of oil from Canarium schweinfurthii (black date) fruits for domestic purpose. Appl Res J 1:41-45
Aruna K, Khan K (2014) Optimization studies on production and activity of lipase obtained from Staphylococcus pasteuri SNA59 isolated from spoilt skin lotion. Int J Curr Microbiol Appl Sci 3(5):326-347

Ashfaque M, Solomon S, Pathak N (2014) Optimization of pretreatment and fermentation conditions for production of extracellular cellulase complex using sugarcane bagasse. Bioinformation 10:606-610. doi:10.6026/97320630010606

Banik RM, Prakash M (2004) Laundry detergent compatibility of the alkaline protease from Bacillus cereus. Microbiol Res 159:135-140. doi:10.1016/j. micres.2004.01.002

Bisht D, Yadav SK, Darmwal NS (2013) An oxidant and organic solvent tolerant alkaline lipase by P. aeruginosa mutant: downstream processing and biochemical characterization. Braz J Microbiol 44(4):1305-1314. doi:10.1590/ S1517-83822013000400040

Bora L, Bora M (2012) Optimization of extracellular thermophilic highly alkaline lipase from thermophilic Bacillus sp. isolated from hot spring of Arunachal Pradesh, India. Braz J Microbol 43:30-42. doi:10.1590/ S1517-83822012000100004

Bujang N, Muhd Rodhi MN, Musa M, Subari F, Idris N, Mohd Mokhtar NS, Ku Hamid KH (2013) Effect of dilute sulfuric acid hydrolysis of coconut dregs on chemical and thermal properties. Procedia Eng 68:372-378. doi:10.1016/j.proeng.2013.12.194

Chauhan M, Chauhan RS, Garlapati VK (2013) Evaluation of a new lipase from Staphylococcus sp. for detergent additive capability. Biomed Res Int 2013:1-6. doi:10.1155/2013/374967

Cheriff S, Mnif S, Hadrich F, Abdelkafi S, Sayadi S (2011) A newly high alkaline lipase: an ideal choice for application in detergent formulations. Lipids Health Dis 10(221):1-8. doi:10.1186/1476-511X-10-221

Costa-silva TA, Souza CRF, Oliveira WP, Said S (2014) Charaterization and spray drying of lipase produced by the endophytic fungus Cercospora kikuchii. Braz J Chem Eng 31(4):849-858. doi:10.1590/0104-6632.20140314s00002880

Dahiya P, Rathi B (2014) Characterization and application of alkaline a-amylase from Bacillus licheniformis MTCC1483 as a detergent additive. Int Food Res J 22(3):1293-1297

Ding TY, Hii SL, Ong LGA (2012) Comparison of pretreatment strategies for conversion of coconut husk fiber to fermentable sugars. BioResources 7(2):1540-1547

Dutta S, Ray L (2009) Production and characterization of an alkaline thermostable crude lipase from an isolated strain of Bacillus cereus $C_{7}$. Appl Biochem Biotechnol 159:142-154. doi:10.1007/s12010-009-8543-x

Goering HK, van Soest PJ (1970) Forage fiber analysis (apparatus, reagents, procedures and some applications). United State Department of Agriculture, Washington

Goto M, Obuchi R, Hirose T, Sakaki T, Shibata M (2004) Hydrothermal conversion of municipal organic waste into resources. Bioresour Technol 93:279-284. doi:10.1016/j.biortech.2003.11.017

Hemlata B, Uzma Z, Tukaram K (2016) Substrate kinetics of thiol activated hyper thermostable alkaline lipase of Bacillus sonorensis 4R and its application in bio-detergent formulation. Biocatal Agric Biotechnol 8:104-111. doi:10.1016/j.bcab.2016.08.008

Hentati D, Chebbi A, Loukil S, Kchaou S, Godon J-J, Sayadi S, Chamkha M (2016) Biodegradation of fluoranthene by a newly isolated strain of Bacillus stratosphericus from Mediterranean seawater of the Sfax fishing harbour, Tunisia. Environ Sci Pollut Res 23:15088-15100. doi:10.1007/ s11356-016-6648-7

Jamrath T, Lindner C, Popovic MK, Bajpai R (2012) Production of amylases and proteases by Bacillus caldolyticus from food industry wastes. Food Technol Biotechnol 50(3):355-361

Jurado E, Bravo V, Luzón G, Fernández-Serrano M, García-Román M, AltmajerVaz D, Vicaria JM (2007) Hard-surface cleaning using lipases: enzyme-surfactant interactions and washing tests. J Surfactants Deterg 10:61-70. doi:10.1007/s11743-006-1009-Z

Kam YC, Hii SL, Sim CY-Y, Ong LGA (2016) Schizophyllum commune lipase production on pretreated sugarcane bagasse and its effectiveness. Int J Polym Sci 2016:1-6. doi:10.1155/2016/2918202

Kanmani P, Kumaresan K, Aravind J (2015) Utilization of coconut oil mill waste as a substrate for optimized lipase production, oil biodegradation and enzyme purification studies in Staphylococcus pasteuri. Electron J Biotechnol 18:20-28. doi:10.1016/j.ejbt.2014.11.003 
Khoo ML, Ibrahim CO (2009) Lipase from thermoalkalophilic Pseudomonas species as an additive in potential laundry detergent formulations. Malays J Microbiol 5(1):1-5. doi:10.21161/mjm.09507

Khoramnia A, Ebrahimpour A, Beh BK, Lai OM (2011) Production of a solvent, detergent and thermotolerant lipase by a newly isolated Actinobacter sp. in submerged and solid state fermentation. J Biomed Biotechnol 2011:1-12. doi:10.1155/2011/702179

Lailaja VP, Chandrasekaran M (2013) Detergent compatible alkaline lipase produced by marine Bacillus smithii BTMS 11. World J Microbiol Biotechnol 29:1349-1360. doi:10.1007/s11274-013-1298-0

Maki M, Leung KT, Qin W (2009) The prospects of cellulase-producing bacteria for the bioconversion of lignocellulosic biomass. Int J Biol Sci 5:500-516

Mobarak-Qamsari E, Kasra-Kermanshashi R, Moosavi-nejad Z (2011) Isolation and identification of a novel, lipase-producing bacterium, Pseudomonas aeruginosa KM110. Iran J Microbiol 3(2):92-98

Nerurkar M, Joshi M, Pariti S, Adivarekar R (2013) Application of lipase from marine bacteria Bacillus sonorensis as an additive in detergent formulation. J Surfactants Deterg 16:435-443. doi:10.1007/s11743-012-1434-0

Niyonzima FN, More SS (2015) Microbial detergent compatible lipase. J Sci Ind Res 74:105-113

Odisi EJ, Silvestrin MB, Takahashi RYU, Castro da Silva MA, de Souza Oliveira, Lima A (2012) Bioprospection of cellulolytic and lipolytic South Atlantic deep-sea bacteria. Electron J Biotechnol. doi:10.2225/ vol15-issue5-fulltext-17

Palaker AA, Vasudevan PT, Yan S (2000) Purification of lipase: a review. Biocatal Biotransform 18:177-200. doi:10.3109/10242420009015244

Prazeres JN, Cruz JAB, Pastor JM (2006) Characterization of alkaline lipase from Fusarium oxysporum and the effect of different surfactants and detergents on the enzyme activity. Braz J Biotechnol 37:505-509. doi:10.1590/ S1517-83822006000400019

Sambrook J, Russell DW (2001) Molecular cloning: a laboratory manual. Cold Spring Harbor Laboratory Press, New York

Sarina S, Abdul Aziz AR, Mohamed Kheireddine A (2013) Optimization and modelling of extraction of solid coconut waste oil. J Food Eng 114:228234. doi:10.1016/j.jfoodeng.2012.08.025

Shivaji S, Chaturvedi P, Suresh K, Reddy GSN, Dutt CBS, Wainwright M, Narlikar JV, Bhargava PM (2006) Bacillus aerius sp. nov., Bacillus aerophilus sp. nov.
Bacillus stratosphericus sp. nov. and Bacillus altitudinis sp. nov., isolated from cryogenic tubes used for collecting air samples from high altitudes. Int J Syst Evol Microbiol 56:1465-1473. doi:10.1099/ijs.0.64029-0

Siddiq M (2012) Tropical and subtropical fruits: postharvest physiology, processing and packaging. Wiley, lowa

Sooch BS, Kauldhar BS (2013) Influence of multiple bioprocess parameters on production of lipase from Pseudomonas sp. BWS-5. Braz Arch Biol Technol 56:711-721. doi:10.1590/S1516-89132013000500002

Sreelatha B, Rao VK, Kumar RR, Girisham S, Reddy SM (2016) Culture conditions for the production of thermostable lipase by Thermomyces lanuginosus. Beni-Suef Univ JAppl Sci. doi:10.1016/j.bjbas.2016.11.010

Sulaiman S, Abdul Aziz AR, Aroua MK (2013) Reactive extraction of solid coconut waste to produce biodiesel. J Taiwan Inst Chem Eng 44:233-238. doi:10.1016/j.jtice.2012.10.008

Tamura K, Peterson D, Peterson N, Stecher G, Nei M, Kumar S (2011) MEGA5: molecular evolutionary genetics analysis using maximum likelihood, evolutionary distance, and maximum parsimony methods. Mol Biol Evol 28(10):2731-2739. doi:10.1093/molbev/msr121

Thakur V, Tewari R, Sharma R (2014) Evaluation of production parameters for maximum lipase production by P. stutzeri MTCC 5618 and scale-up bioreactor. Chi J Biol 2014:1-14. doi:10.1155/2014/208462

Vetayasuporn S (2007) The feasibility of using coconut residue as a substrate for oyster mushroom cultivation. Biotechnol 6:578-582. doi:10.3923/ biotech.2007.578.582

Wang H, Zhong S, Ma H, Zhang J, Qi W (2012) Screening and characterization of a novel alkaline lipase from Acinetobacter calcoaceticus 1-7 isolated from Bohai bay in China for detergent formulation. Braz J Microbiol 2012:148-156. doi:10.1590/S1517-838220120001000016

Weerasooriya MKB, Kumarasinghe AAN (2012) Isolation of alkaline lipase from rubber seed-partial purification, characterization and its potential applications as a detergent additive. Indian J Chem Technol 19:244-249

Winkler VK, Stuckmann M (1979) Glycogen, hyaluronate and some other polysaccharides greatly enhance the formation of exolipase by Serratia marcescens. J Bacteriol 138(3):663-670

Zainuddin MF, Shamsudin R, Mokhtar MN, Ismail D (2014) Physicochemical properties of pineapple plant waste fibers from the leaves and stems of different varieties. BioResources 9(3):5311-5324

\section{Submit your manuscript to a SpringerOpen ${ }^{\circ}$ journal and benefit from:}

- Convenient online submission

- Rigorous peer review

- Open access: articles freely available online

- High visibility within the field

- Retaining the copyright to your article

Submit your next manuscript at $\boldsymbol{\nabla}$ springeropen.com 